\section{GLOFs and Politics}

In his keynote presentation, "Fools rush in," Jack Ives notes that a United Nations University study of hazards in Kakani and Khumbu (Nepal) concluded that GLOFs represent the most serious mountain hazard in those areas, a conclusion underscored soon afterward by the outbreak of Dig Tsho, near Thame.

Political contingencies have hampered GLOF research and mitigation efforts. Essential aerial photography was classified as secret. Ives' recommendation that ICIMOD take a lead in studying and mapping the hazards was ignored by ICIMOD under Dr Rosser. Although DrVic Galay and individual staff members of the Water and Energy Commission provided assistance for Ives' research, His Majesty's Government (HMG) ignored their recommendations. Only after global warming had become a sexy topic in the mid-1990s did ICIMOD (with UNEP support) produce an inventory of potentially hazardous glacial lakes in Nepal and Bhutan.

\section{Arun III Hydro-Electric Power Project}

Jack Ives gives a semi-insider's account of the politicization of GLOF hazards as pertains to the aborted Arun III hydropower project. According to Ives it was due to the generalized GLOF fears that the World Bank and HMG undertook a narrowly focused review of the project in 1995. Only GLOF threats in the Arun Valley itself were to be discussed, and all other factors were excluded from the review. While there was no evidence of a GLOF hazard to the hydropower site itself, Teiji Watanabe passed on to Ives his findings about the serious GLOF threat posed by Imja Lake in the neighboring valley.

\title{
Volunteer expedition brings modern health care to Rolwaling
}

I $n$ the fall of 2000, I spent a month in Rolwaling as a member of Bridges-PRTD ("Projects in Rational Tourism Development"), a private volunteer/study abroad company that had was trying to help promote backpacker tourism as a resource for economic development. (See www.bridges-prtd.com.) We were quartered at the main village of Beding (3700m), some thirty drab houses clustered around a small monastery about six days' trek up from the road head at Dolakha. At the time, there was no electricity, no health clinic, no functioning school. The monastery was dilapidated and the stupa had been washed away by a GLOF. Every able-bodied man and most of the women had left to work elsewhere as porters and guides, leaving only a few dozen women, children, and lamas to tend the fields.

Although our resources were limited, we did set up a handful of teahouses - merely by providing signs and English menus; we bought some paint and lumber and gave the gompa a face-lift; we identified and marked a suitable waste disposal site; we gave a few lectures on first aid, and donated a trunk-load of medical supplies. A Kathmandu engineering firm was hired to produce a feasibility study and design for a micro-hydro plant.

Since 2003, Bridges-PRTD had suspended operations due to the political instability in Nepal. As often happens with small development efforts, we had raised hopes but failed to follow through with the kind of assistance that might make a long-term difference.

Last October I was finally able to pull together an expedition of health care professionals with the objective of decisively upgrading healthcare facilities in Beding and sharing with this remote community the advantages of modern science. The team included my wife Jody Swoboda Etters, Medical Director Laurie Strasburger PA-C, Ken Zawaki MD, Ami Zawaki MD, Kristi LaRock PA-C, Clairane Vost RN, Tom Willard EMT, Vannessa
Willard, Eddie Sandoval and Perry LaRock. Our support network included anthropologist Janice Sacherer, climber Nick Arding, Everest veterans Jon Gangdal and Dawa Chirri Sherpa of the Rolwaling Foundation, and Scott MacLennan and his staff at the Mountain Fund. Unlike the situation that prevailed back in 2000, when virtually no one outside Nepal had heard of Rolwaling, there is now an international web of individuals and groups interested in both the valley and its people.

On the trail north along the Tamba, not much had changed since 2000 . The road had been extended to Singate, which meant we didn't have to deal with the 2000m descent (and ascent, coming back) just northeast of Dolakha. There were no signs of the sort of prosperity you see along the Everest trail - the fact that Rolwaling had been closed to independent trekkers for thirty years meant that most visitors passed through in self-contained caravans, contributing precious little to the economy. The Maoist insurgency effectively removed the official restrictions on travel, but few tourists wanted to face being shaken down for a "contribution."

At our first stop, we happened on a man carrying his eleven-year-old daughter in a dhoko, a conical wicker basket supported by a tumpline over his head. They were coming from Simigaon, racing toward the hospital in Dolakha, although they had no money and were not optimistic about getting help. It turned out that the girl had a serious kidney infection which had lead to sepsis. For two days we treated her with intravenous fluids and antibiotics. It was touch-and-go the first night, but when we parted ways she was walking and on her way to recovery. We were soon besieged by requests for medical assistance.

In Beding, there were signs of activity. A new stupa had been constructed, a new school built and staffed, and a diversion project had been along the river - not 
Ives was able to argue that if Imja gave way, the catastrophe would cause such consternation that it would likely derail the nearby Arun III project. According to Ives, this argument proved trenchant; in the end, it was fear of bad publicity, rather than concern for human safety and ecological sustainability, that led the German and Japanese to withdraw their support, and killed the project.

John Reynolds provides a somewhat more nuanced but not necessarily contradictory account of the demise of Arun III. According to Reynolds, the main consultants to the project had given the go-ahead on the basis of outdated maps which showed no glacial lakes in the area. Alert members of the Water and Energy Commission Secretariat (WECS) staff showed Reynolds much more recent photographs that revealed there were indeed glacial lakes in the Arun

to mitigate a potential lake outburst, but to control the normal monsoon floods. The Rolwaling Foundation is moving ahead with plans for a small hydropower plant to supply households with electricity as well as to develop local lodges so that independent backpacker tourism can finally take off.

After settling into the host families' homes, the team was welcomed to the village with a tea ceremony in which all the community members offered katas (ceremonial scarves) and blessings to the volunteers. Following the ceremony, we set to work. There was a side room attached to the school, and we converted that into a clinic, installing furniture and medical supplies. Solar panels provide light and charging capacity for small equipment, including a microscope donated by Colorado Mountain Medical, a clinic in Vail, Colorado. At the same time, we undertook public health improvements in areas such as sanitation, drinking water, waste management, nutrition and first aid training.

Meanwhile we were training Jangmu, the Nepali nurse hired to run the clinic on a long-term basis. Together we treated villagers for a variety of complaints. There were relatively few acute infections and injuries, while chronic and persistent disorders were much more prevalent. Respiratory diseases, cataracts, arthritis, tooth decay, gingivitis, and arthritis are all too common. While we were able to deal with most problems, several could not be addressed without more advanced diagnostics. A few members of the community may have cancer and other life threatening illnesses, but without making the trek to Katmandu, we couldn't be sure, much less provide effective treatment.

During the ten days we spent in the Rolwaling Valley, we also encountered a substantial demand for medical services on the part of tourists. Despite the fact that most packaged tours had medical supplies and trained staff, we were called on to provide assistance for quite a few cases of altitude sickness. As tourist traffic increases, we expect this need to increase.

We have begun to look for resources to address catchment. At the request of the World Bank, Reynolds produced a "notional scheme" to assess the actual hazard and was granted $\$ 500,000$ to carry it out, but the entire scheme was suddenly aborted; to date, no glacial hazard assessment has ever been carried out in the Arun Valley. Reynolds reports that the Germans withdrew because they

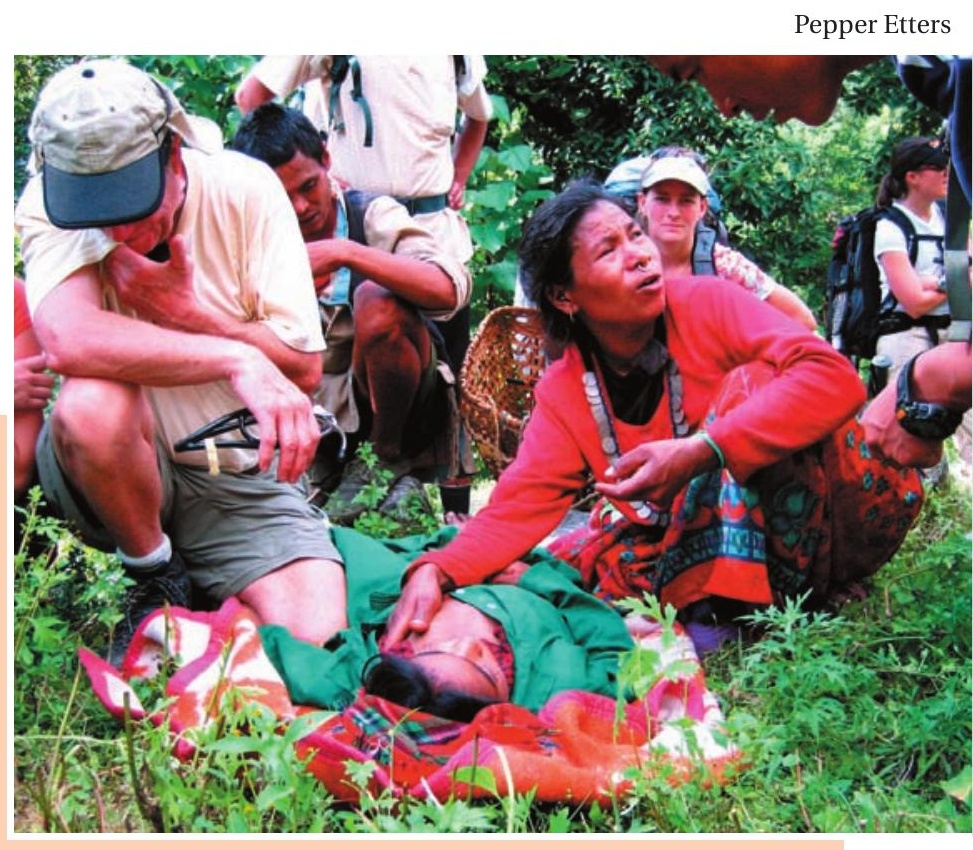

these issues and hope to bring volunteer specialists including dentists and oral surgeons, eye surgeons and orthopedists as well as additional general practitioners who will continue to train and support Jangmu and her eventual successors so that they can continue to care for the community with whom they have been entrusted.

On a personal note, I would like to add that I am saddened by the recent death of Sir Edmund Hillary. Both as a member of Bridges-PRTD and as the organizer of this medical expedition, I have been keenly aware that we are following in the huge footsteps of the man who gave the world an enduring model of volunteer development. Sir Edmund undertook only those projects specifically requested. He made it clear that he was undertaking this work out of gratitude for Sherpa collaboration on a project that had brought him immense personal satisfaction (as well as world fame). He didn't proselytize or set conditions; he came and personally participated in the projects; and he returned, again and again and again. I hope that the death of Sir Edmund will remind people of his work, and the work that remains to be done. The need is great, and the experience is life-transforming.

\section{Pepper Etters}

Pepper Etters directs Rolwaling Health Care Project, and owns Adventurous Spirit Photography (http:// www.adventurousspiritphoto.com/splash.php). 